\title{
Opportunities for improving digital competences: expectations and findings on a national and international ground
}

\author{
Reka Racsko \\ Eszterházy Károly College \\ racsko@ektf.hu
}

\begin{abstract}
The opportunities for applying learning environments has a distinctive role in the studies on this field. In my presentation I aim to cast light upon the most important terms and their structures not to mention the opportunities for embedding them into the well-known practice. I also explore the most significant international studies on this case, which all pays a special attention on understanding digital competences and finding the possibilities for improvement. I wish to fill my audience in on the background that lies within the framework of its existence greatly relying on information, communication, content-construction, security and problem-solving. I also wish to take the framework of competences for the "digital citizenship" into consideration as defined by ISTE (International Society for Technology in Education) and several Hungarian researchers (Lévai, Ollé et al. 2013). Based on the aforementioned studies I also wish to introduce the requirements for achieving the status of a digital citizen as set up by national legislation (National Information and Communications Technology Strategy 2014-2020 in: The Hungarian National Curriculum) and also by the EU (EU 2020). In the closing section of my presentation I elaborate on analyzing and contrasting the consequences of assessing students' achievement (PISA 2012; TIMSS; PIRLSS) and defining the possible success-factors on a national scale. The international assessment puts a special focus on measuring the digital competence and its direct effect on other competences.
\end{abstract}

Keywords: information literacy, digital competence, digital citizenship

\section{Introduction}

In my study I compared the elements of information literacy, digital competence and the main principles of Digital Agenda for Europe and National Informational 
and Communications Strategy .And I also wish to take the framework of competences for the "digital citizenship" into consideration, as defined by ISTE (International Society for Technology in Education). A recent research of University of California shows that an average American consumes information 12 hours a day. It equals about 100.000 words or $30 \mathrm{~GB}$ of information. The question is: Based on our information literacy (or digital competence) how much of all can we process? We must pay attention to education, because a quarter of all pupils in Europe have poor reading competences, one in seven young people leave education and training too early.

\section{Explanation of Terminology}

There are many misconceptions in connection with information literacy, while its real definition is often left out. Paul Zurkowsky [1] is credited with coining the term Information Literacy in 1974. Nowadays, however, various inaccurate versions of the term are also in use: information education, information culture, information competency, information ability, information knowledge.

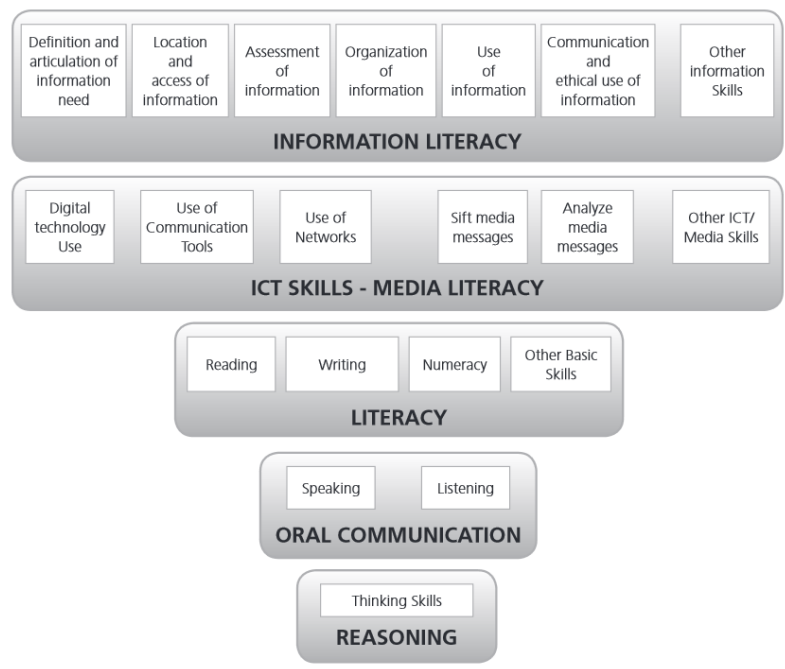

Figure 1: The UNESCO's Communication Skills Constellation [2]

Based on UNESCO's constellation of communication skills [3] information literacy is recognized as having a primary role in our everyday lives as it consists of the need for information, operations with information and its critical evaluation.

On the level of information literacy, skills in Information and Communication Technology (ICT) and media literacy are a prerequisite, as they encompass the notion of digital technology, collaborate networking, and the conscious and critical use of media. The basic skills are located below these levels. 
The definition of Information Literacy has been altered during the years. According to a number of researchers (Dömsödy, Koltay, Herzog), the ideal wording of the term of information literacy is as follows: "Those who have acquired information literacy know when and why they are in need of information; where to find and how to evaluate it, how to use and communicate the gained information ethically." [4]

The conceptual framework of Informational Literacy is based on United Nations Educational, Scientific and Cultural Organization definition.[5]

The IL is a part of our knowledge and the capacity of people to:

- Recognise their information needs;

- Locate and evaluate the quality of information;

- Store and retrieve information;

- Make effective and ethical use of information, and

- Apply information to create and communicate knowledge.

If we were to plays this in a larger frame, we can outline the Communication Skills Constellation. In this figure we can determine that the digital competence is includes ICT skills, and both of them parts are of information literacy.

Digital literacy, which is often mentioned as a synonym for information literacy [5]means "the combination of awareness, attitude and skills, with the help of which we are able to use the digital devices and institutions properly for identifying, accessing, handling, integrating, evaluating and synthesising the digital sources, as well as for creating new bits of knowledge and media expression, and for being able to communicate with others and reflect on this process." [6]

Digital literacy, according to the European Commission's working definition, is "the totality of competencies necessary for the acquisition of digital competency." [7] Digital literacy, however, is not reduced to computer literacy, although it is often identified with it in Hungary.

Digital competence is a transversal key competence which, as such, enables us to acquire other key competences (e.g. language, mathematics, learning to learn, cultural awareness). It is related to many of the 21st Century skills which should be acquired by all citizens, to ensure their active participation in society and the economy.

Today this field also appears in the digital agenda of the strategic framework of EU 2020.

\section{Exceptations and findings}

\subsection{Research DigComp2013}

Research DigComp 2013 [8] targets on helping to understand digital competency and its framework. The study is the result of a lengthy social consultation, and gives 
a detailed description on digital competency for every European citizen. Besides the detailed account, competencies, bits of knowledge, skills and attitudes are also described.

It recommends 3 levels of knowledge for every competency, and with the help of a developmental indicator system everyone can measure their level of digital competency. Its five pillars are information, communication, content creation, security and problem solving.

The DIGICOMP research presents a detailed framework for the development of digital competence of all citizens.

It consists of detailed descriptions of all competences that are necessary to be proficient in digital environments and describes them in terms of knowledge, skills, and attitudes. Three proficiency levels are suggested for each competence.

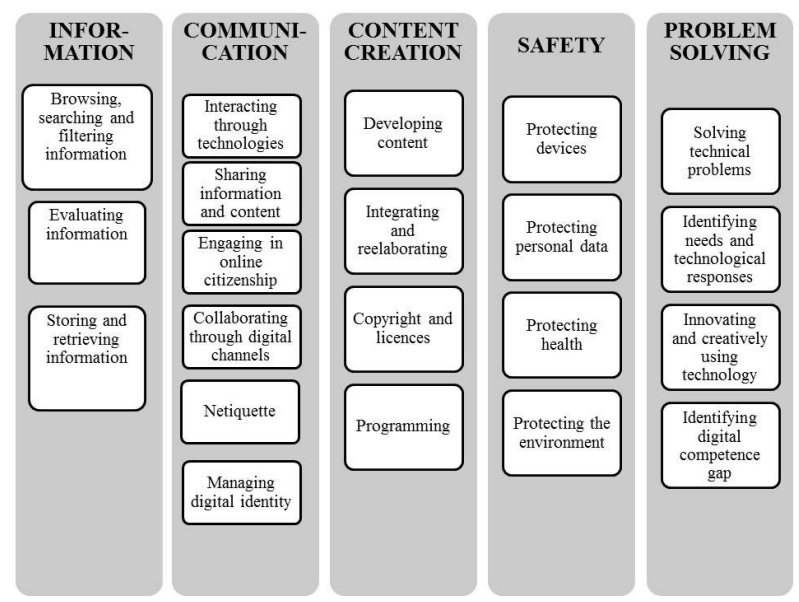

Figure 2: Digital (ICT) competence areas and the competeces [9]

\subsection{Flagship Initiative: A Digital Agenda for Europe}

The models appear in the expectations: The European Union's Flagship Initiative: "A Digital Agenda for Europe's" aim is to increase support in the field of ICTs. At EU level, the Commission will work:

- To reform the research and innovation funds and increase support in the field of ICTs so as to reinforce

- Europe's technology strength in key strategic fields

- To promote internet access and take-up by all European citizens, especially through actions in support of digital literacy and accessibility. 


\subsection{National Information and Communication Strategy}

The National Informational and Communications Strategy is supported by 3 developing pillars : digital competences, digital economy and digital state.

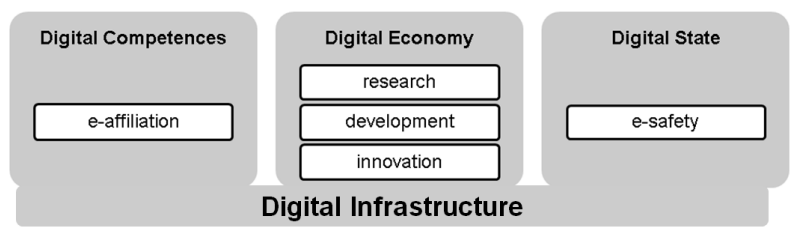

Figure 3: Key elements of National Informational and Communications Strategy (Hungary) 2014-2020 [10]

\subsection{The model of Digital Citizenship}

The model for digital citizenship was developed by the International Society for Technology in Education (ISTE) by synthetizing more theories, and it the contains the following competencies: digital access, digital literacy, digital communication, digital responsibility, digital etiquette, digital security, digital trade, digital law, digital health and wellness [11]

The International Society for Technology in Education has an Educational Standards for students, it consists of 5 element:

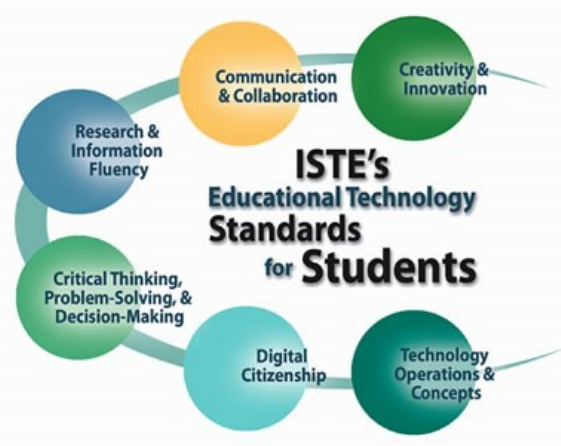

Figure 4: Digital citizenship standards of International Society for Technology in Education [13]

Similar elements can be traced in the Hungarian model [12] in a slightly nuanced approach: communication, access, device usage, digital health, digital self-portrait, digital cohabitation, value production, productivity, time management and content management.

Digital citizenship today exceeds the notions of information literacy, media literacy and digital literacy, they are, however, included in its new conception, 
adding online productive presence to them.

\section{Students Assessments Programs (PISA 2009)}

The Students Assessments Programs help to get comparable data for the country's, and helps to find the way of development.

In 2009 PISA conducted a survey of digital literacy among 15-year-old students. PISA wanted to find out whether boys and girls are as ready for the digital age as they - and we - think they are. As the latest issue of PISA in Focus shows, while many students may have the technological skills, not all have the cognitive skills to fully capitalize on technology to access, manage, integrate and evaluate digital information. [14 ]On average, PISA results show that student performance in digital reading is closely related to performance in print reading, meaning that those students who are proficient in reading texts on paper are also proficient in reading texts on a screen. But in some countries, such as Australia and Korea, students score significantly higher in digital reading than in print reading; while in other countries, for example Hungary, Poland and Colombia, students are better in print reading than in digital reading. Expectations are in correlation with constellation models.

\section{Conclusion}

The national and international expectations, the elements of digital citizenship focus on today's issues, though they have the flexibility to accommodate technology changes in the foreseeable future.

The elements provide a framework for understanding the technology issues that are important to educators. They should be used to identify current areas of need in a school or district technology program, as well as emerging issues that may become increasingly important in coming years.

In order to able to develop these competences we need to improve the abilities of teachers, who can pass this knowledge onto their students.

Finally I would like to close my presentation with a quote by Nelson Mandela:

"There can be no keener revelation of a society's soul than the way in which it treats its children and their teachers." [15]

\section{References}

[1] ZURKOWSKY, P., The Information Service Environment Relationships and Priorities. Related Paper No. 5. (1974) cited by KIS-TÓTH L.: Trends in e-learning environments. International Scientific and Professional Conference XXVI.DIDMATECH 2013. ISBN 978-80-8122-086-9 (2013) 27. 
[2] CATTS, R.L, JESUS, Towards Information Literacy Indicators: Conceptual framework paper. UNESCO Paris ( 2008), 18. http://www.uis.unesco.org/Library/ Documents/wp08_InfoLit_en.pdf

[3] same as [2]

[4] Chartered Institute of Library and Information (2010), 138-146.

[5] Gilster, P. (1997): Digital literacy. New York: Wiley. cited by KOLTAY T. Médiamúveltség, média-írástudás, digitális írástudás. Médiakutató. (2009 tél)

[6] ALEXANDRIA PROCLAMATION 2005, adopted by UNESCO's Information for All Programme (IFAP)

[7] Kovácsné K., Á., Digitális múveltség Európában. Tudományos és múszaki tájékoztatás. (2009) 56. évfolyam 6. szám,

[8] Ferrari, A., Punie, Y.-B N.,DigComp: A Framework for developing and Understanding Digital Competence in Europe. Report EUR 26035. Joint Research Centre (2009)

[9] same as [8]

[10] Nemzeti Infokommunikációs Stratégia 2014-2020. http://www.kormany.hu/ download/d/37/f0000/Nemzeti $\% 20$ Infokommunik\%C3\%A1ci $\%$ C3\%B3s $\% 20$ Strat $\%$ C3\% A9gia\%202014-2020.pdf

[11] Ribble, M. Excerpted from Digital Citizenship in Schools Second Edition. (2013): http://www.iste.org/docs/excerpts/DIGCI2-excerpt.pdf

[12] Ollé J. , Lévai D., et al. Digitális állampolgárság az információs társadalomban. Budapest: Eötvös Kiadó (2014)

[13] Ribble, M., Excerpted from Digital Citizenship in Schools Second Edition. (2013) http://www.iste.org/docs/excerpts/DIGCI2-excerpt.pdf

[14] PISA 2012 Results in Focus What 15-year-olds know and what they can do with what they know. http://www.oecd.org/pisa/keyfindings/ pisa-2012-results-overview.pdf Hungary 2009/2010: Country Report on ICT in Education. European Schoolnet. URL: http://insight.eun.org http://www.oecd.org/pisa/keyfindings/pisa-2012-results-overview.pdf

[15] Hargraves, A., Fullan, M. Professional Capital: Transforming Teaching in Every School. Teachers College Press (2012), 18 